\title{
THE LINKAGE BETWEEN STOCK PRICE AND ECONOMIC GROWTH IN AUSTRALIA: A CHICKEN-AND-EGG PARADOX?
}

\author{
Chor Foon Tang ${ }^{a}$
}

${ }^{a}$ Department of Economics, Faculty of Economics and Administration, University of Malaya, 50603 Kuala Lumpur, Malaysia, tcfoon@yahoo.com

\section{ARTICLE INFO}

Article data:

- Received: 18 June 2012

- Accepted: 3 January 2013

JEL classification: C22, F43, O11

Keywords:

- Australia

- Economic Growth

- Stock Price

- Recursive Causality Test

\section{ABSTRACT}

This study attempts to re-investigate the linkage between stock prices and economic growth in Australia using the cointegration and Granger causality tests. The study covers the quarterly data from 1960:Q1 to 2008:Q4. The cointegration test exhibits that the variables are cointegrated, implying that stock prices and economic growth in Australia are moving together in the long-run. Nevertheless, the TYDL causality test suggests that there is only a unidirectional causality running from stock prices to economic growth. Moreover, the recursive regression-based TYDL causality test affirms that this unidirectional causality is stable over their respective period of analysis. Therefore, the relationship between stock prices and economic growth in Australia is no longer a chicken-and-egg paradox.

Reference to this paper should be made as follows: Tang, C.F. 2013. The linkage between stock price and economic growth in Australia: A chicken-and-egg paradox?, Ekonomska istraživanja Economic Research 26(2):396-412. 


\section{INTRODUCTION}

The aim of this study is to re-investigate the interaction between stock price and economic growth in Australia within the cointegration and causality framework. The relationship between stock price and economic growth has been an age-old issue in both economics and also finance literatures; nevertheless its causal relationship remains a chicken-and-egg phenomenon. Some empirical evidences showed that stock price is a good indicator to predict future economic growth because a well-developed stock market would effectively mobilize savings to productive investment which in turn lead to economic growth. This is the so-called supply-leading relationship highlighted in Patrick (1966). With respect to this the direction of causality presumably running from stock price to economic growth (e.g., Lee, 1992; Kaplan, 2008; Liu and Sinclair, 2008; Shahbaz et al., 2008). On the contrary, other empirical studies defended the views that economic growth induces stock price to change because economic growth would create demand for stock and other financial instruments, then the stock and financial markets would effectively respond to these changes. Patrick (1966) named this as the demand-leading relationship. For this reason, the direction of causality is expected to flow from economic growth to stock price (e.g., Know and Shin, 1999; Gjerde and Saettem, 1999). ${ }^{1}$ Obviously, the causality direction between stock price and economic growth remains yet an unresolved conundrum. In view of policy implication, Georges (2001) noted that the stock market development played a significant role in policy transmission mechanisms. Therefore, knowledge of the linkage between stock price and economic growth is necessary for investors and also decision makers to formulate a proper investment and economics management strategy.

As far as Australia is concerned, empirical study on the relationship between stock price and economic growth is quite scarce and their finding also failed to reach unanimous consensus. A summary of the earlier studies on the relationship between stock price and economic growth in Australia is delineated in Table 1.As presented in Table 1, Lamberton (1958) found that over half a century the stock price and economic growth in Australia is positively correlated. Next, Tuncer and Alövsat (2000) used the time series data from 1981 to 1998 to assess the causal relationship between stock price and economic growth for 20 economies. ${ }^{2}$ In the case of Australia, they found that stock price and economic growth are not Granger-causes each other. In other words, the causal relationship between stock price and economic growth in Australia is neutral. On the contrary, Shan et al. (2001) attempted to re-investigate the causal relationship between stock price and economic growth in Australia using the modified Wald (MWALD) causality test advocated by Toda and Yamamoto (1995). The study covered the quarterly sample from 1976:Q3 to 1998:Q3. Contrary with the finding of Tuncer and Alövsat (2000), they discovered a strong bilateral causality between the stock price and economic growth in Australia.

\footnotetext{
${ }^{1}$ Extremely, Hu (1993) and Stock and Watson (1998) found that the relationship between stock price and economic growth is neutral.

${ }^{2}$ The 20 economies includes the United States of America, Germany, Australia, Austria, Great Britain, Belgium, France, South Africa, India, Indonesia, Spain, Sweden, Italy, Canada, Japan, Norway, Pakistan, Turkey, New Zealand, and Greece.
} 


\section{TABLE 1: SUMMARY OF SELECTED EMPIRICAL STUDIES ON THE RELATIONSHIP BETWEEN STOCK MARKET AND ECONOMIC GROWTH}

\section{IN AUSTRALIA}

\begin{tabular}{|c|c|c|c|c|c|c|}
\hline \multirow[t]{2}{*}{ Authors } & \multirow[t]{2}{*}{$\begin{array}{l}\text { Research } \\
\text { Period }\end{array}$} & \multicolumn{2}{|l|}{$\begin{array}{l}\text { Econometric } \\
\text { Methods }\end{array}$} & \multicolumn{3}{|l|}{$\begin{array}{l}\text { Empirical } \\
\text { Results }\end{array}$} \\
\hline & & Cointegration & Causality & Cointegration & $\begin{array}{l}\text { Causality } \\
\text { Direction }\end{array}$ & $\begin{array}{l}\text { Stock } \\
\text { market- } \\
\text { economic } \\
\text { growth } \\
\text { relation }\end{array}$ \\
\hline Lamberton (1958) & $\begin{array}{l}1901- \\
1956\end{array}$ & - & - & - & - & Positive \\
\hline Tuncer and Alövsat (2000) & $\begin{array}{l}1981- \\
1994\end{array}$ & - & $\begin{array}{l}\text { Sims (1972) - } \\
\text { VAR }\end{array}$ & - & $S P \leftrightarrow Y$ & - \\
\hline Shan et al. (2001) & $\begin{array}{l}\text { 1976:Q3- } \\
\text { 1998:Q3 }\end{array}$ & - & $\begin{array}{l}\text { Toda and } \\
\text { Yamamoto } \\
\text { (1995)- } \\
\text { MWALD }\end{array}$ & - & $S P \leftrightarrow Y$ & - \\
\hline Thangavelu and Ang (2004) & $\begin{array}{l}\text { 1969:Q1- } \\
\text { 1999:Q4 }\end{array}$ & $\begin{array}{l}\text { Johansen- } \\
\text { Juselius (1990) }\end{array}$ & $\begin{array}{l}\text { Granger } \\
\text { (1969) -VAR }\end{array}$ & $\begin{array}{l}\text { Not } \\
\text { Cointegrated }\end{array}$ & $S P \rightarrow Y$ & - \\
\hline \multirow[t]{9}{*}{ Mao and Wu (2007) } & $\begin{array}{l}\text { 1974- } \\
\text { 2004: }\end{array}$ & $\begin{array}{l}\text { Johansen- } \\
\text { Juselius (1990) }\end{array}$ & $\begin{array}{l}\text { Granger } \\
\text { (1988)- } \\
\text { VECM }\end{array}$ & & & \\
\hline & Monthly & & & Cointegrated & $S P \leftrightarrow Y$ & 0.243 \\
\hline & Quarterly & & & Cointegrated & $Y \rightarrow S P$ & 0.613 \\
\hline & $\begin{array}{l}\text { 1974- } \\
\text { 1983: }\end{array}$ & $\begin{array}{l}\text { Johansen- } \\
\text { Juselius (1990) }\end{array}$ & $\begin{array}{l}\text { Granger } \\
\text { (1988)- } \\
\text { VECM }\end{array}$ & & & \\
\hline & Monthly & & & Cointegrated & $S P \leftrightarrow Y$ & 0.057 \\
\hline & Quarterly & & & $\begin{array}{l}\text { Not } \\
\text { Cointegrated }\end{array}$ & $Y \rightarrow S P$ & - \\
\hline & $\begin{array}{l}\text { 1986- } \\
2004:\end{array}$ & $\begin{array}{l}\text { Johansen- } \\
\text { Juselius (1990) }\end{array}$ & $\begin{array}{l}\text { Granger } \\
(1988)- \\
\text { VECM }\end{array}$ & & & \\
\hline & Monthly & & & Cointegrated & $S P \leftrightarrow Y$ & 0.304 \\
\hline & Quarterly & & & Cointegrated & $Y \rightarrow S P$ & 0.690 \\
\hline
\end{tabular}

Note: $S P$ and $Y$ denotes stock price and economic growth, respectively. $\rightarrow$ represents the unidirectional causality. The $\leftrightarrow$ and $\leftrightarrow$ imply bilateral causality, and no causality, respectively.

As a value added to the earlier studies, Thangavelu and Ang (2004) applied both Johansen and Juselius (1990) multivariate cointegration and Granger causality tests to re-examine the linkages between stock price and economic growth in Australia over the period of 1969:Q1 to 1999:Q4. Their empirical evidence suggested that stock price and economic growth in Australia are not cointegrated. Notwithstanding, they found evidence of a unidirectional causality runs from stock price to economic growth in Australia. Recently, Mao and $\mathrm{Wu}$ (2007) re-examined the relationship with different sample period and also frequency of data (i.e., monthly and quarterly). In order to achieve the objective of the study, they employed the Johansen-Juselius cointegration and Granger causality tests to assess the relationship between stock price and economic growth in Australia. Remarkably, the Johansen-Juselius cointegration test results show that the variables are cointegrated regardless to which sample period and data frequency is employed. Therefore, they concluded that stock price and economic growth in Australia are moving together in the 
long-run. In view of causality direction, the results of Granger causality test showed that economic growth Granger-causes stock price whenever quarterly data is used. Ironically, the Granger causality evidence for monthly data is inconclusive.

Owing to the ambiguous relationship presented by the previous studies and their attendant policy implications, it is pertinent for this study to re-investigate the linkages between stock price and economic growth in Australia. This study differs from the earlier studies in three novel ways. First, we employ the bounds testing approach to cointegration to examine the presence of a long-run equilibrium relationship between stock price and economic growth in Australia. On the basis of Monte Carlo experiment, Pesaran and Shin (1999) and also Panopoulou and Pittis (2004) claimed that this cointegration approach has superior properties over the conventional cointegration tests (e.g., Engle and Granger, 1987; Johansen and Juselius, 1990). Moreover, it could be applied to test for cointegration even when the variables are purely $I(0)$, purely I(1) or mutually cointegrated.

Second, the earlier studies have utilised asymptotic methods to test for causality which is proven to be low power when the variables are characterized by non-spherical probability distributions and the presence of autoregressive conditional heteroskedasticity (ARCH) problem (see Hacker and Hatemi-J, 2006). Therefore, we use the TYDL causality test (Toda and Yamamoto, 1995; Dolado and Lütkepohl, 1996) and leveraged bootstrap approach to test for causality between stock price and economic growth. As far as our research is concerned, this approach has not been adopted to study the causal relationship between stock price and economic growth. Third, we follow Tang's (2008a) and Tang and Tan's (2013) suggestion to incorporate the recursive procedure into the TYDL causality test to examine the stability of the causal relationship between stock price and economic growth. To the best of our knowledge, no author has hitherto demonstrated the stability or persistency of the stock price-growth relationship. Therefore, our study can provide more reliable results and robust contribution to the literature of causal relationship between stock price and economic growth.

The remainder of this paper is structured as follows. Section 2 provides a brief discussion on model specifications, econometric methods and data used in this study. In Section 3, we report our empirical results. Finally, the conclusion of this study will be presented in Section 4.

\section{MODEL SPECIFICATION, ECONOMETRIC METHODS AND DATA}

\section{A. Model Specification}

The interest of this study is to examine the interaction between stock price and economic growth in Australia, hence we estimate the bivariate framework as expressed in equation (1). On the basis of this bivariate framework, many of the published articles on the relationship between stock price and economic growth have utilized the similar bivariate model. Among them are Binswanger (2000), Padhan (2007), Mao and Wu (2007), Kaplan (2008), and Liu and Sinclair (2008).

$$
\ln Y_{t}=\alpha_{0}+\alpha_{1} \ln S P_{t}+\varepsilon_{t}
$$


where In denotes the natural logarithm. $Y$ is the real gross domestic product (GDP) and $S P$ represent the real stock price. The random error terms $\varepsilon_{t}$ are assumed to be spherically distributed and white noise. The economic theories suggest that the expected sign of $\alpha_{1}$ can be either positive or negative.

\section{B. Econometric Methods}

As all other studies that utilize time series data, it is of utmost important to recognize and discuss the analytical tools used to achieve the objective of a research work. We begin with describing the Pesaran et al. (2001) bounds testing approach to cointegration. Then, we define the Toda and Yamamoto (1995) and Dolado and Lütkepohl (1996) test statistics and the leverage bootstrap critical values to ascertain the causality direction. Ultimately, we describe the recursive regression-based causality test suggested by Tang (2008a) to investigate the stability of causal relationship between stock price and economic growth in Australia. The following sub-section will briefly explain the testing procedure for each analytical tool.

\section{i. Bounds Testing Approach to Cointegration}

This study adopted the bounds testing approach to cointegration developed by Pesaran et al. (2001) to examine the presence of long-run equilibrium relationship between stock price and economic growth. This cointegration test is estimated within the autoregressive distributed lag (ARDL) framework. Although the primary objective of this study was focused on the causality direction between stock price and economic growth in Australia, the existence of co-movement relationship between the variables is of paramount importance in avoiding spurious regression phenomenon. There are several advantages of using the bounds testing approach to cointegration. First, the ARDL approach can be applied irrespective of whether the independent variables are purely I(0), purely I(1) process or mutually cointegrated. Second, this approach does not push the short run dynamic into the residuals term as in the Engle and Granger (1987) residuals-based cointegration test (see Pattichis, 1999). Hence, it is relatively more reliable than the conventional cointegration tests, in particular for study with a finite sample.

In order to account for the long-run equilibrium relationship through the bounds testing approach to cointegration, we estimate the following ARDL equation:

$$
\Delta \ln Y_{t}=a_{0}+a_{1} \ln Y_{t-1}+a_{2} \ln S P_{t-1}+\sum_{i=1}^{k} b_{1 i} \Delta \ln Y_{t-i}+\sum_{i=0}^{k} b_{2 i} \Delta \ln S P_{t-i}+e_{t}
$$

where $\Delta$ is the first difference operator and $k$ is the maximum lag length. The residuals $e_{t}$ are assumed to be white noise, normally and identically distributed. Next, we investigate the existence of a long-run relationship by restricting the lagged level variables $\ln Y_{t-1}$ and $\ln S P_{t-1}$ in equation (2). Obviously, this is a joint significance F-test for the null hypothesis of not cointegrated $\left(H_{0}: a_{1}=a_{2}=0\right)$ versus the alternative hypothesis of cointegrated $\left(H_{A}: a_{1} \neq a_{2} \neq 0\right)$. Pesaran et al. (2001) tabulated two sets of asymptotic bounds critical values 
- upper bounds critical value, $/(1)$ and lower bounds critical value, $/(0)$. If the calculated Fstatistics for cointegration test is greater than their respective upper bounds critical value, we surmise that the estimated variables are cointegrated. On the contrary, if the calculated F-statistic is less than the lower bounds critical values, then we cannot reject the null hypothesis of no cointegrating relation. Nevertheless, it must be pointed out here that if the calculated F-statistics fall within the upper and lower bounds critical values, the inference would be inconclusive and the degree of integrated must be known before any cointegration conclusion can be drawn (see Pesaran et al., 2001).

\section{ii. Causality Method}

Here, we briefly describe the causality method used in this study. We employ the causality method developed by Toda and Yamamoto (1995) and Dolado and Lütkepohl (1996) or more popularly known as TYDL causality test to investigate the causal link between stock price and economic growth within the augmented-VAR system. Zapata and Rambaldi (1997) performed a Monte Carlo experiment and found that both the likelihood ratio test and the Wald test are very sensitive to the specification of the short-run dynamics in error-correction models (ECMs), even in large samples. Prior to ascertain the causal relationship, we have to determine the optimal lags structure $(k)$ accommodated into the VAR model and the maximal order of integration $\left(d_{\max }=1\right)$ for the variables in the system. Therefore, the augmented-VAR system in levels can be written as follows:

$$
\begin{aligned}
& {\left[\begin{array}{c}
\ln Y_{t} \\
\ln S P_{t}
\end{array}\right]=\left[\begin{array}{l}
\beta_{1} \\
\beta_{2}
\end{array}\right]+\left[\begin{array}{ll}
B_{11,1} & B_{12,1} \\
B_{21,1} & B_{22,1}
\end{array}\right] \times\left[\begin{array}{l}
\ln Y_{t-1} \\
\ln S P_{t-1}
\end{array}\right]+\mathrm{L}+\left[\begin{array}{ll}
B_{11, k} & B_{12, k} \\
B_{21, k} & B_{22, k}
\end{array}\right] \times\left[\begin{array}{c}
\ln Y_{t-k} \\
\ln S P_{t-k}
\end{array}\right]} \\
& +\left[\begin{array}{ll}
B_{11, p} & B_{12, p} \\
B_{21, p} & B_{22, p}
\end{array}\right] \times\left[\begin{array}{l}
\ln Y_{t-p} \\
\ln S P_{t-p}
\end{array}\right]+\left[\begin{array}{l}
\xi_{1 t} \\
\xi_{2 t}
\end{array}\right]
\end{aligned}
$$

where In denotes as natural logarithm. The lags' order of $p$ represents the $(k+1)$ and $k$ is the optimal lags' order of the VAR system. The residuals $\left(\xi_{1 t}, \xi_{2 t}\right)$ are assumed to be white noise, normally and identically distributed. In equation (3), $B_{12, k} \neq 0 \forall_{k}$ implies that $\ln S P$ Grangercauses $\ln Y$, whereas $\ln Y$ Granger-causes $\ln S P$ if $B_{21, k} \neq 0 \forall_{k}$.

Ironically, Shukur and Mantalos (2000) stated that the TYDL causality test may be biased in analysis with small and medium sample size. Hacker and Hatemi-J (2006) conducted a Monte Carlo analysis on size distortion properties. They found that the Wald test performed badly when the residuals are not spherically distributed and the ARCH effect exist in the VAR system. In this respect, the leveraged bootstrap approach suggested by Hacker and Hatemi-J (2006) will be used to compute the bootstrap critical values. If the computed TYDL statistic is greater than the simulated bootstrapped critical values, the null hypothesis of non-Granger causality should be rejected. Otherwise, we cannot reject the null hypothesis of non-Granger causality. Due to the extensive discourses done on the leveraged bootstrap approach, the 
interested readers can refer to Hatemi-J and Roca (2004), Hatemi-J and Irandoust (2005), Hacker and Hatemi-J (2006), and Hatemi-J and Irandoust (2006) for details discussion.

\section{iii. Recursive Regression-based Causality Test}

Apart from the standard causality test explained in above, this study will also employ the recursive regression-based causality test suggested by Tang (2008a) and Tang and Tan (2013) to examine the stability of the causal relationship between stock price and economic growth in Australia. The recursive regression-based TYDL causality test can be described as follows. Initially, the TYDL causality test is estimated for the beginning subsample of $T$ observations, i.e., with an initial sample size $T$. After that, a new observation is added into the end of the estimation sample period (i.e. $T+1$ ). This relationship is then re-estimated with the Ordinary Least Squares (OLS) estimator. For example, if we start at 10 years, that is, $T=40$ observations, the first TYDL causality test statistic was obtained by using a subsample period from 1960:Q1 to 1969:Q4 (i.e. $T=40$ observations). Then the second test statistic was obtained by using data from 1960:Q1 to 1970:Q1. This recursive regression procedure will continue until the last observation was used to examine the causal relationship. Finally, the generated $\chi^{2}$ - statistics are normalized by the 5 per cent critical values, meaning that if the normalized TYDL statistic is more than unity then the null hypothesis is rejected. ${ }^{3}$

\footnotetext{
${ }^{3}$ The normalized TYDL statistic can be calculated by dividing the TYDL statistics with the 5 per cent critical values. Hence, if the normalized TYDL statistic exceeded unity, meaning that the TYDL statistics is greater than the 5 per cent critical values. On the other hand, the normalized TYDL statistics will be less than unity if the TYDL statistic is lower than the 5 per cent critical values.
} 


\section{iv. Data Source}

In this study, we used quarterly data from the period 1960:Q1 to 2008:Q4. The quarterly data for Australia were extracted from International Financial Statistics (IFS), published by the International Monetary Fund (IMF). The variables employed in this study consist of stock price index $(2000=100)$ and Gross Domestic Product (GDP). The GDP deflator $(2000=100)$ was used to transform the series into the real term.

\section{EMPIRICAL RESULTS}

\section{A. Unit Root Test Results}

It is well established in the econometric literature that it is essential to determine the degree of integration for each series to avoid the spurious regression problem (Granger and Newbold, 1974; Phillips, 1986) and the validity of bounds test to cointegration. Although the bounds testing approach to cointegration does not require a pre-testing of the degree of integration, it is important to ensure that the variables under consideration are not integrated at an order higher than one and the dependent variable in the ARDL equation is an /(1) process variable. This is because the critical values tabulated in Pesaran et al. (2001) are no longer valid if the ARDL equation included the $I(2)$ variables. For this reason, we applied the Augmented Dickey-Fuller (ADF, 1979, 1981) and Phillips-Perron (PP, 1988) unit root tests to assess the degree of integration of the variables under investigation $\left[\ln Y_{t}, \ln S P_{t}\right]$.

TABLE 2: THE RESULTS OF UNIT ROOT TESTS

\begin{tabular}{lll}
\hline \hline Variables & ADF & PP \\
\hline $\ln Y_{t}$ & $-2.941(9)$ & $-2.218(6)$ \\
$\Delta \ln Y_{t}$ & $-4.423(8)^{* * *}$ & $-14.580(4)^{* * *}$ \\
$\ln S P_{t}$ & $-2.215(3)$ & $-1.785(5)$ \\
$\Delta \ln S P_{t}$ & $-11.265(0)^{* * *}$ & $-11.352(3)^{* * *}$ \\
\hline \hline
\end{tabular}

Note: The asterisk ${ }^{* * *}$ denotes the significance level at the 1 per cent. ADF and PP refer to Augmented Dickey-Fuller and Phillips-Perron unit root tests. The optimal lag length of ADF test is selected using the AIC while the bandwidth for PP test is selected using the Newey-West Bartlett kernel. Figure in parentheses denotes the optimal lag length and bandwidth. The critical values for ADF and PP tests are obtained from MacKinnon (1996).

Source: Author's calculation

Interestingly, both the ADF and PP unit root test results reported in Table 2 indicate that all the estimated series are integrated of order one, I(1) process. These results corroborate with the findings of Nelson and Plosser (1982) that most of the macroeconomics variables are non-stationary at level, but are stationary after first differencing. 
With this evidence, we can proceed to investigate the presence of a potential long-run equilibrium relationship between stock price and economic growth in Australia via the bounds testing approach to cointegration.

\section{B. Cointegration Test Results}

The initial step in applying the bounds testing approach to cointegration is to determine the optimal combination of lag order for each variable in the ARDL equation. According to Enders (2004), maximum lags order of 3 years or 12 quarters are relatively long to capture the dynamic behavior in a time series analysis. In this context, we begin at 12 lags order and used the Akaike's Information Criterion (AIC) to select an optimal combination lag order. The AIC statistics reveal that ARDL $(8,4)$ is the best combination. Then, the calculated F-statistic for cointegration together with the critical values and a battery of diagnostic tests on the final ARDL model are reported in Table 3.

TABLE 3: THE RESULTS OF BOUNDS TEST FOR COINTEGRATION

\begin{tabular}{lll}
\hline \hline Calculated F-statistic & & \\
\hline$F_{Y}(\ln Y \mid \ln S P)$ & $9.983^{* * *}$ & \\
\# Critical values (F-test): & & \\
Significance Level & Lower I(0) & Upper /(1) \\
1 per cent & 6.84 & 7.84 \\
5 per cent & 4.94 & 5.73 \\
10 per cent & 4.04 & 4.78 \\
Conclusion: & Cointegrated & \\
\hline \hline
\end{tabular}

Note: The asterisk ${ }^{* * *}$ denotes significance level at the 1 per cent. \# Case III: Unrestricted intercept and no trend $(\mathrm{k}=1)$ critical values are obtained from Pesaran et al. (2001).

R-squared: 0.280; Adjusted R-squared: 0.217; F-Statistic: 4.444 (0.000);

Jarque-Bera: 3.392 (0.183); Ramsey RESET [1]: 1.447 (0.229);

Breusch-Godfrey LM test [1]: 0.102 (0.749), [2]: 0.775 (0.679);

ARCH test [1]: 1.775 (0.183), [2]: 3.588 (0.166).

[ ] refer to the diagnostics tests order; ( ) refer to the p-values.

Source: Author's calculation

The Ramsey RESET test failed to reject the null hypothesis of no specification error implying that the model is correctly specified. The Breusch-Godfrey LM test demonstrated that the residuals are free from serial correction problem up to order two. Similarly, the autoregressive conditional heteroskedasticity $(A R C H) L M$ test exhibits that the variance of the residuals is constant over time. Moreover, the Jarque-Bera normality test suggests that the residuals are normally distributed. This implied that the standard statistical tests (i.e., R-squares, $t$-statistics, and F-statistics) are valid. 
Nevertheless, the plot of CUSUM of Squares statistics crossed the 5 per cent critical bounds (see Figure 1) implying that the estimated coefficients are not stable over the period of 1975 to 2000. The plausible explanation is the point raised by Narayan and Smyth (2005) that in the first half of 1970s the Australian economy was affected by various external shocks such as world economic shock, a commodity price shock, and the external inflationary pressure. Subsequently, the structural break at the late 1990s and 2000 may be owing to the Asian and Russian economic crises and the slowdown of the United States economy.

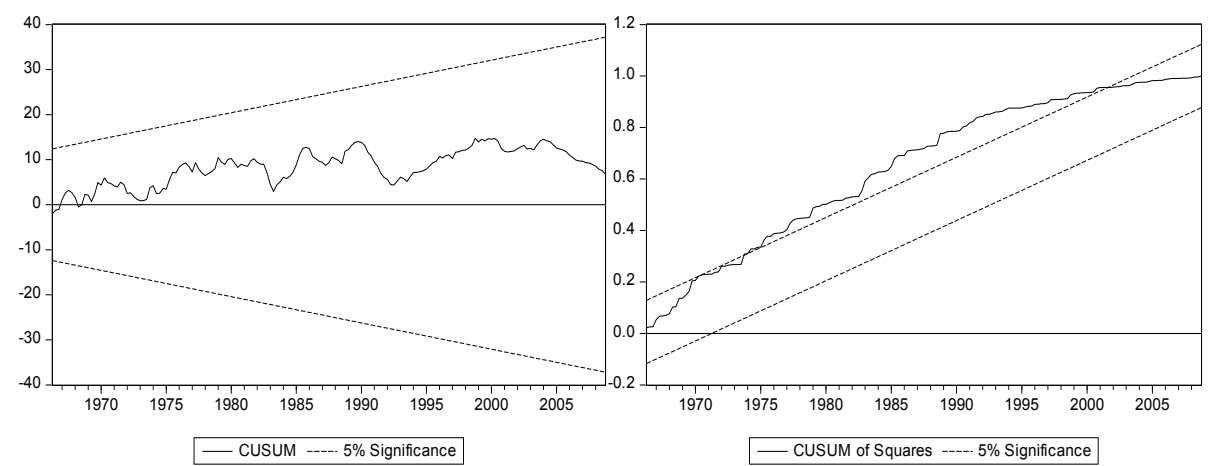

Figure 1: The plots of CUSUM and CUSUM of Squares Statistics

SOURCE: Author's calculation

Beyond that, for testing the presence of long-run equilibrium relationship between stock price and economic growth, the calculated F-statistic is greater than the 1 per cent upper bounds critical value. Thus, we surmise that stock price and economic growth in Australia are comove in the long run over the analysis period of 1960 to 2007. This result is parallel with the finding of Mao and Wu (2007), but it is contrary with Thangavelu and Ang (2004) study. Since the variables are cointegrated, we estimate the long-run coefficients with four different long-run estimators to check for robustness of the estimation and also to provide more efficient long-run results. In this study we employ the Ordinary Least Squares (OLS) approach advocated by Engle and Granger (1987), the Fully-Modified OLS (FMOLS) approach suggested by Phillips and Hansen (1990), the Dynamic OLS (DOLS) approach suggested by Stock and Watson (1993), and the Autoregressive Distributed Lag (ARDL) approach suggested by Pesaran and Shin (1999). The estimated long-run coefficients are presented in Table 4.

Interestingly, the four estimators provide similar results for the long-run coefficients of stock price and thus affirming that the estimated results are robust. The sign of the long-run coefficient, $\ln S P_{t}$ is positive and statistically significant at the 5 per cent level. In addition, the long-run coefficient for stock price ranges from 0.57 to 0.88 . This implies that a 1 per cent increase in stock price is likely to increase real GDP for Australia's by less than 1 per cent (i.e., inelastic positive relationship). This result is corroborated with the findings of Lamberton (1958), Fama (1981), and Mao and Wu (2007). 
TABLE 4: THE RESULTS OF LONG-RUN ELASTICITIES

\begin{tabular}{llll}
\hline \hline No. & Cointegrating estimators & \multicolumn{2}{l}{ Cointegrating vector } \\
\cline { 3 - 4 } & & $\ln S P_{t}$ & \multicolumn{1}{l}{ Constant } \\
1. & Engle and Granger (1987) - OLS & $0.573^{* * *}$ & $9.101^{* * *}$ \\
2. & Phillips and Hansen (1990) - FMOLS & $0.647^{* *}$ & $8.797^{* * *}$ \\
3. & Stock and Watson (1993) - DOLS & $0.575^{* * *}$ & $9.056^{* * *}$ \\
4. & Pesaran and Shin (1999) - ARDL & $0.881^{* * *}$ & $9.307^{* * *}$ \\
\hline \hline
\end{tabular}

Note: The asterisks ${ }^{* * *}$ and ${ }^{* *}$ denotes the significant level at the 1 and 5 per cent levels, respectively. (1) OLS - Ordinary Least Squares; (2) FMOLS - Fully Modified OLS; (3) DOLS - Dynamic OLS; (4) ARDL - Autoregressive Distributed Lag. Source: Author's calculation

\section{TYDL Causality Test Results}

The presence of cointegrating relations between stock price and economic growth implied that there must be Granger-causality in at least one direction, but cointegration doesn't indicate the direction of causation (Tang, 2008b). The application of TYDL causality test requires information about the lag order $(k)$ and maximum order of integration $\left(d_{\max }\right)$ for each variable in the VAR system. In the present study, the optimal lag order was determined by using AIC. The AIC statistic chose $k=5$ as the optimal lag order, hence we estimated an augmented-VAR $(k+1)$ model and then calibrated the TYDL test statistics to ascertain the causality direction.

TABLE 5: THE RESULTS OF CAUSALITY TESTS (TYDL)

\begin{tabular}{|c|c|c|c|c|}
\hline \multirow[t]{2}{*}{ Null Hypothesis } & \multirow{2}{*}{$\begin{array}{l}\text { Estimated } \\
\text { TYDL tests }\end{array}$} & \multicolumn{3}{|c|}{ Leveraged bootstrap critical values } \\
\hline & & 1 per cent & 5 per cent & 10 per cent \\
\hline $\ln S P_{t} \nrightarrow \ln Y_{t}$ & $28.130^{* * *}$ & 15.697 & 11.651 & 9.635 \\
\hline $\ln Y_{t} \nrightarrow \ln S P_{t}$ & 2.858 & 14.352 & 10.926 & 9.005 \\
\hline
\end{tabular}

Note: The asterisk ${ }^{* * *}$ denotes statistically significance at the 1 per cent level. The GAUSS codes were used to perform causality test and compute the leveraged bootstrap critical values.

Source: Author's calculation

The TYDL statistics together with the leveraged bootstrap critical values are reported in Table 5. The causality test results clearly indicate that the null hypothesis of stock price does not Granger-cause economic growth is rejected at the 1 per cent significance level. At the same time, the null hypothesis of economic growth does not Granger-causes stock price cannot be rejected at the 10 per cent significance level. Therefore, our empirical evidence supports unidirectional causality running from stock price to economic growth in Australia rather than reversal causation.

However, another caveat is that the causal relationship between variables may not be stable due to frequent changes in the global economic and political environments (Tang, 2008a). 
In this regards, the TYDL causality test using the entire sample period may not reflect such changes. To confirm whether the causal relationship between stock price and economic growth in Australia is stable, the recursive regression approach was incorporated into the TYDL causality test at different lag order (i.e., 4, 5, 8, and 12 lags). ${ }^{4}$

From the visual inspection of Figure 2, we found that the causal relationship between stock price and economic growth in Australia is relatively stable over the analysis period from 1960 to 2008 regardless of which lag order is used. Specifically, the normalized TYDL statistics are consistently rejected the null hypothesis of stock price does not Granger-causes economic growth, except for the period from 1975 to 1978 (see Figure 2(a)). This is nothing to surprise and it is correlated with the economic shocks suggested by CUSUM of Squares statistics (see Figure 1). On the other hands, the normalized TYDL causality test statistics failed to reject the null hypothesis of economic growth does not Granger-causes stock price over the recursive sample period (see Figure 2(b)). Based on the time-varying causality test results, we affirmed that there is a stable unidirectional causality running from stock price to economic growth. This implies that stock market development is always the best indicator or yardstick for future economic growth in Australia. Ironically, our finding also shows that the movement in stock price is not strongly determined by economic growth. This implication may be attributed to the reason that investors are sensitive and overreact to news or even rumors, hence stock market may not be driven by economic growth (Mookerjee and $\mathrm{Yu}, 1999$ ). Ultimately, the finding of this study gained little evidence that the causal relationship between stock market and economic growth in Australia is not a chicken-and-egg paradox as there is a strong and stable unidirectional causality running from stock price to economic growth.

\section{CONCLUSION}

In this paper we re-investigate the stock market development and economic growth nexus for the Australian economy through the bounds testing approach to cointegration and TYDL causality test. In addition to that, we also test the stability of the causal relationship between stock market and economic growth by using the recursive regression-based causality approach. The bounds testing approach to cointegration shows that stock price and economic growth are cointegrated in Australia. This implies that stock price and economic growth have a long-run equilibrium relationship, even though deviations from the steady state may exist in the short run.

Turning to the causality test, this study used the leveraged bootstrap approach to TYDL causality and found strong evidence of unidirectional causality running from stock price to economic growth in Australia; however there is no evidence of reverse causality. Additionally, the recursive regression-based causality test suggests that the causal relationship between stock price and economic growth is stable over the analysis period as the causality inferences are consistent over time.

\footnotetext{
${ }^{4}$ Thornton and Batten (1985) argued that causality results are sensitive to the lag length selected for causality test. 
Given these unidirectional causality results, we may conclude that the causal relationship between stock market and economic growth in Australia is no longer a chicken-and-egg phenomenon. As a result, this study attempts to suggest that policymakers may use the stock price as a leading indicator to predict the future economic growth in Australia as the causality tests showed that stock price is consistently Granger-causes economic growth. On the contrary, the findings of this study may also indicate that any negative shocks in the stock market may imply some signals of economic turbulence ahead. For equity investment purposes, investors should not solely depend on the economic environment to judge the future stock market performance, as economic growth in Australia may be not a significant element to influence the stock market development. Therefore, investors are advised to employ fundamental and technical charting analyses on individuals stock or industry in helping them to optimise the rate of return from an investment.

Figure 2: The results of time-varying causality test

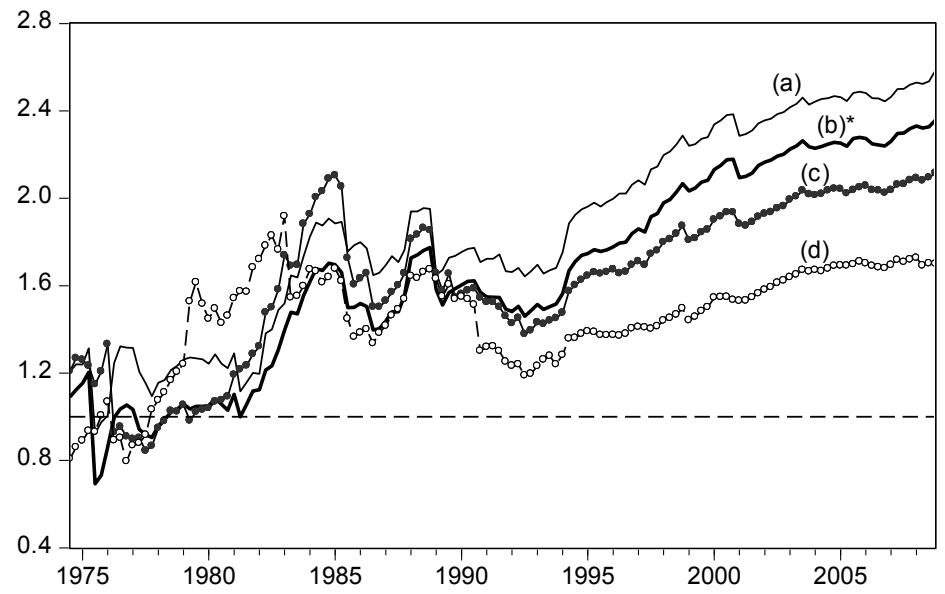

(a) $H_{0}: \ln S P_{t} \nrightarrow \ln Y_{t}$ 


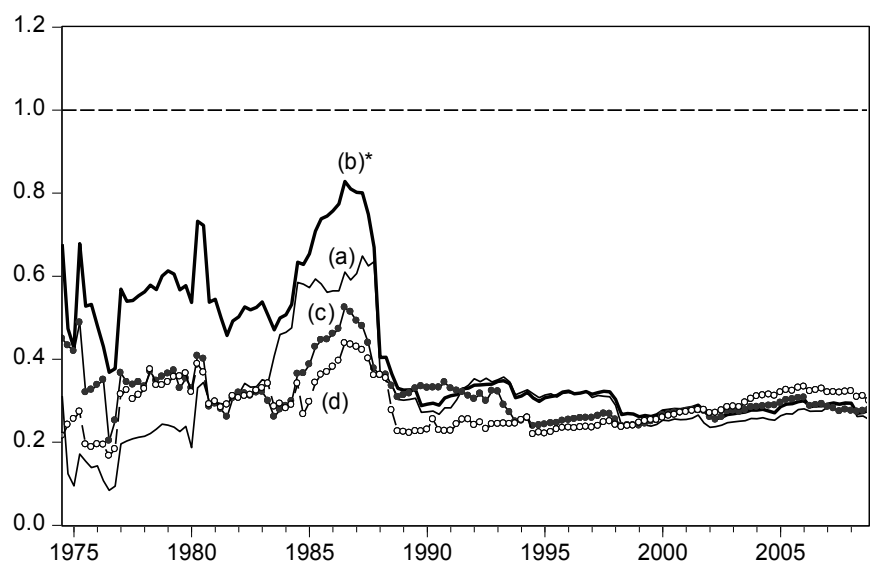

(b) $H_{0}: \ln Y_{t} \nrightarrow \ln S P_{t}$

Note: The above are the time-varying causality tests for the null hypothesis of (a) Stock price does not Granger causes economic growth and (b) Economic growth does not Granger causes stock price. $\rightarrow$ denotes non-Granger causes. The notation (a), (b), (c), and (d) denote the lag orders of 4, 5, 8, and 12 in the VAR system. The asterisk * indicate the optimal lag order selected by AIC.

Source: Author's calculation

\section{Acknowledgement:}

I would like to thank the anonymous reviewers for their insightful comments and suggestions on the earlier draft of this research. In addition, I would also like to thanks Abdulnasser Hatemi-J for sharing his GAUSS programming codes to generate the bootstrap critical values for small sample. Any shortcomings that remain in this research paper are purely the author's.

\section{REFERENCES}

Binswanger, M. "Stock returns and real activity: Is there still a connection?" Applied Financial Economics 10(2000):379-387.

Caporale, G.M., Howells, P.G.A. and Soliman, A.M."Stock market development and economic growth: The causal linkage."Journal of Economic Development 29 (2004): 33-50.

Dickey, D.A. and Fuller, W.A."Distributions of the estimators for autoregressive time series with a unit root."Journal of the American Statistical Association 74 (1979): 427-431.

Dickey, D.A. and Fuller, W.A."Likelihood ratio statistics for autoregressive time series with a unit root." Econometrica 49 (1981): 1057-1072.

Dolado, J.J. and Lütkepohl, H.“Making Wald tests work for cointegrated VAR system." Econometric Reviews 15 (1996): 369-386.

Enders, W.Applied Econometric Time Series(2nd ed.).New York: John Wiley \& Sons, 2004.

Engle, R.F. and Granger, C.W.J.“Co-integration and error-correction: Representation, estimation and testing." Econometrica 55 (1987): 251-276.

Fama, E.F."Stock returns, real activity, inflation, and money." American Economic Review 71(1981): 545-565. 
Georges, W."The credit channel of monetary policy transmission: Evidence from stock returns." Economic Inquiry 39 (2001): 74-85.

Gjerde, O. and Saettem, F."Causal relations among stock returns and macroeconomic variables in a small, open economy."Journal of International Financial Markets, Institutions and Money 9(1999): 61-74.

Granger, C.W.J. and Newbold, P.“Spurious regression in econometrics.”Journal of Econometrics 2 (1974): 111-120.

Hacker, R.S. and Hatemi-J, A."Tests for causality between integrated variables using asymptotic and bootstrap distribution: Theory and application." Applied Economics 38 (2006): 14891500.

Hatemi-J, A. and Irandoust, M.“Energy consumption and economic growth in Sweden: A leveraged bootstrap approach, (1965-2000)."International Journal of Applied Econometrics and Quantitative Studies 2(2005): 87-98.

Hatemi-J, A. and Irandoust, M."A bootstrap-corrected causality test: Another look at the money-income relationship." Empirical Economics 31 (2006): 207-216.

Hatemi-J, A. and Roca, E.D."An examination of the equity market price linkage between Australia and the European Union using leveraged bootstrap approach." The European Journal of Finance 10 (2004): 475-488.

Hu, Z."The yield curve and real activity." IMF Staff Papers 40(1993): 781-806.

Johansen, S. and Juselius, K."Maximum likelihood estimation and inference on cointegration with applications to the demand for money." Oxford Bulletin of Economics and Statistics52 (1990):169-210.

Kaplan, M. "The impact of stock market on real economic activity: Evidence from Turkey."Journal of Applied Sciences 8(2008): 374-378.

Know, C.S. and Shin, T.S."Cointegration and causality between macroeconomic variables and stock market returns." Global Finance Journal 10(1999): 71-81.

Lamberton, D.M.“Economic growth and stock prices: The Australian experience.”Journal of Business 31(1958): 200-212.

Lee, B.S."Causal relations among stock returns, interest rates, real activity, and inflation."Journal of Finance 47(1992): 1591-1603.

Liu, X.H. and Sinclair, P."Does the linkage between stock market performance and economic growth vary across Greater China." Applied Economics Letters, 15 (2008): 505-508.

MacKinnon, J.G. "Numerical distribution functions for unit root and cointegration tests."Journal of Applied Econometrics 11 (1996): 601-618.

Mao, Y.J. and Wu, R.F."Does the stock market act as a signal for real activity? Evidence from Australia." Economic Papers 26(2007): 180-192.

Masih, A.M.M. and Masih, R.“Does money cause prices, or the other way around? Multi-country econometric evidence including error-correction modelling from South-east Asia."Journal of Economic Studies 25(1998): 138-160.

Mookerjee, R. and Yu, Q."An empirical analysis of the equity market in China." Review of Financial Economics 8 (1999): 41-60.

Narayan, P.K. and Smyth, R."Structural breaks and unit roots in Australian macroeconomic time series." Pacific Economic Review 10(2005): 421-437.

Nelson, C.R. and Plosser, C.I. "Trends and random walks in macroeconomic time series: Some evidence and implications."Journal of Monetary Economics10(1982): 139-162.

Newey, W. and West, K."A simple positive semi-definite, Heteroskedasticity and Autocorrelation Consistent Covariance Matrix." Econometrica 55 (1987): 703-708. 
Padhan, P.C."The nexus between stock market and economic activity: An empirical analysis for India." International Journal of Social Economics 34(2007): 741-753.

Panopoulou, E. and Pittis, N."A comparison of autoregressive distributed lag and dynamic OLS cointegration estimators in the case of a serially correlated cointegration error." Econometrics Journal 7 (2004): 585-617.

Patrick, H.T."Financial development and economic growth in underdeveloped countries." Economic Development and Cultural Change 14(1966): 174-189.

Pattichis, C.A."Price and income elasticities of disaggregated import demand: Results from UECMs and an application." Applied Economics 31 (1999): 1061-1071.

Pesaran, M.H. and Shin, Y."An autoregressive distributed lag modelling approach to cointegration analysis." In Econometrics and Economic Theory in the 20th Century. The Ragnar Frisch Centennial Symposium, ed. Steinar Strom. Cambridge: Cambridge University Press, 1999.

Pesaran, M.H., Shin, Y. and Smith, R.J."Bounds testing approaches to the analysis of level relationships."Journal of Applied Econometrics 16 (2001): 289-326.

Phillips, P.C.B.“Understanding spurious regressions in econometrics."Journal of Econometrics 33 (1986): 311-340.

Phillips, P.C.B. and Hansen, B."Statistical inference in Instrumental variables regression with /(1) processes." Review of Economic Studies 57(1990): 99-125.

Phillips, P.C.B. and Perron, P.“Testing for a unit root in time series regression." Biometrika 75 (1988): 335-359.

Shahbaz, M., Ahmed, N. and Ali, L."Stock market development and economic growth: ARDL causality in Pakistan."International Research Journal of Finance and Economics 14 (2008): 182-195.

Shan, J.Z., Morris, A.G. and Sun, F."Financial development and economic growth: An egg-andchicken problem?" Review of International Economics 9(2001): 443-454.

Shukur, G. and Mantalos, P."A simple investigation of the Granger-causality test in integratedcointegrated VAR systems."Journal of Applied Statistics 27 (2000): 1021-1031.

Stock, J.H. and Watson, M.W."A simple estimator of cointegrating vectors in higher order integrated systems." Econometrica 61(1993): 783-820.

Stock, J.H. and Watson, M.W."Business cycle fluctuations in U.S. macroeconomic time series."NBER Working Paper 6528, 1998.

Tang, C.F. "Wagner law versus Keynesian hypothesis: New evidence from recursive regressionbased causality tests." ICFAl Journal of Public Finance 6(2008a): 29-38.

Tang, C.F."An empirical modelling on savings behaviour in Malaysia." Labuan Bulletin of International Business and Finance 6 (2008b): 57-76.

Tang, C.F. and Tan, E.C."How stable is the tourism-led growth hypothesis in Malaysia? Evidence from disaggregated tourism markets." Tourism Management 37 (2013): 52-57.

Thangavelu, S.M. and Ang, B.J."Financial development and economic growth in Australia: An empirical analysis." Empirical Economics, 29 (2004): 247-260.

Thornton, D.L. and Batten, D.S."Lag-length selection and tests of Granger causality between money and income."Journal of Money, Credit, and Banking 17(1985): 164-178.

Toda, H.Y. and Yamamoto, T."Statistical inference in vector autoregressions with possibly integrated process."Journal of Econometrics 66 (1995):225-250.

Tuncer, G.C. and Alövsat, M."Stock markets and economic growth: A causality test." Dogus University Journal 2 (2000): 124-132.

Zapata, H.O. and Rambaldi, A.N."Monte Carlo evidence on cointegration and causation."Oxford Bulletin of Economics and Statistics 59 (1997): 285-298. 


\title{
VEZA IZMEĐU CIJENE DIONICA I EKONOMSKOG RASTA U AUSTRALIJI: PARADOKS KOKOŠI I JAJETA?
}

\begin{abstract}
SAŽETAK
Ovaj rad pokušava ponovno istražiti vezu između cijena dionica i ekonomskog rasta u Australiji koristeći testove kointegracije i Grangerove kauzalnosti. Studija pokriva kvartalne podatke od 1960:Q1 do 2008:Q4. Kointegracijski test pokazuje da su varijable kointegrirane, te se podrazumijeva da se, dugoročno gledano, cijene dionica i ekonomski rast u Australiji kreću zajedno. Ipak, TYDL kauzalni test sugerira da postoji samo jednosmjerna kauzalnost koja ide od cijena dionica prema ekonomskom rastu. Osim toga, TYDL test kauzalnosti zasnovan na rekurzivnoj regresiji potvrđuje da je ova jednosmjerna kauzalnost stabilna kroz cijeli analizirani period. Stoga, veza između cijena dionica i ekonomskog rasta u Australiji više nije nalik paradoksu kokoši i jajeta.
\end{abstract}

Ključne riječi: Australija; ekonomski rast; cijena dionica; rekurzivni test kauzalnosti 
Chor Foon TANG
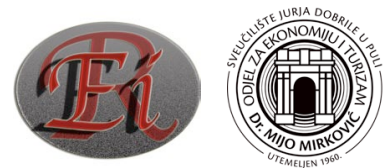